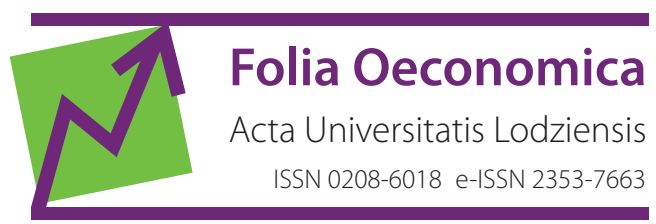

www.czasopisma.uni.lodz.pl/foe/

4(336) 2018

DOI: http://dx.doi.org/10.18778/0208-6018.336.01

\author{
Anna Edyta Szymańska \\ University of Łódź, Faculty of Economics and Sociology, Department of Insurance, \\ szymanska@uni.lodz.pl
}

\title{
The Application of Bühlmann-Straub Model with Data Correction for the Estimation of Net Premium Rates in Bonus-Malus Systems of the Motor Third Liability Insurance
}

\begin{abstract}
One of the elements used in the process of tariff calculation of premiums in motor liability insurance is a bonus-malus system. This systems takes into account the "claims ratio" by means of increases and discounts of the base premium called net premium rates. The aim of this work is to propose an estimation method of the net premium rates in the bonus-malus classes of the motor third-party liability insurance portfolio of individuals. The Bühlmann-Straub model was used for the premium estimation. In order to improve the credibility of the estimated premium rates, a data correction in the classes with premium increase was preformed. An example of the application of the new method is presented based on the data obtained from one of the insurance companies operating on the Polish market, which has reserved the right to stay anonymous.
\end{abstract}

Keywords: credibility theory, Bühlmann-Straub model, bonus-malus system, net premiums rates, motor third liability insurance

JEL: G22, C11, C51

\section{Introduction}

In motor liability insurance premium calculation process consists of two stages: a priori and a posteriori ratemaking (Antonio, Valdez, 2012). The first is the determination of net premiums, using actuarial methods based on certain risk factors, known as the basic ratemaking variables (Ostasiewicz, 2000). The premium so defined and increased, among others, by the costs of insurance operations and the security addition is known as the base premium. The second stage of ratemaking consists in the base premium increases and discounts depending on individual risk factors of the insured. One of the components of the posterior ratemaking, 
commonly used in Europe, are the bonus-malus systems (Lemaire, 1995: 3-4). These systems differentiate the premium, with respect to the number of claims reported by the insured in the previous insurance period. On the Polish market, insurers offer bonus-malus systems which differ in terms of the number of classes, premium rates and the rules of the transition between the classes of the system (Szymańska, 2014: 43-44). The amount of contributions determines the technical result achieved in the given type of insurance. In the case of motor liability insurance, in 2015, a record loss of more than one billion zlotys has been reported (Raport o stanie sektora ubezpieczeń po III kwartale 2015).

The aim of this paper is to propose a method of the estimation of the premium rate of the bonus-malus system based on the maximum likelihood method and comparison of the estimated increases and discounts of premiums with the ones used in the audited insurance company. In the estimation of the maximum likelihood premium the Bühlmann-Straub model has been used. In order to improve the reliability of the estimated premium rates, a data correction in the classes with premium increase was used. An example of the application of the new method based on the data obtained from one of the insurance companies operating on the Polish market, which has reserved the right to stay anonymous, was presented.

\section{The calculation of the insurance premium with the credibility method}

Let $X_{i j}$ denote the total amount of claims paid (or the number of claims) for the $i$-th insured (the $i$-th sub-group) in the $j$-th year of insurance. Suppose that the insurer has observations $x_{i j}, i=1, \ldots, N, j=1, \ldots, t$, which are the realizations of random variables $X_{i j}$. The amounts of payments $x_{i, t+1}$ in year $t+1$ are not known.

Let us assume that for each $i$ the distribution of the random variable $X_{i j}$ depends on parameter $\theta_{i}$ and that random variables $X_{i j}$ by given $\Theta_{i}=\theta_{i}$ are independent and have the same distribution. Random vector $\mathbf{X}_{i}=\left(X_{i 1}, \ldots, X_{i}\right)$ denotes the individual history of insurance for the policy $i$ (i-th sub-group) in a portfolio consisting of $N$ policies (sub-groups). The aim of the insurer is to determine the net premium in the year $t+1$ for the contract and the ( $i$-th sub-group), given the vector $\mathbf{x}_{i}=\left(x_{i 1}, \ldots, x_{i t}\right)$.

Assuming the equivalence of claims and premiums - net premium $m\left(\theta_{\mathrm{i}}\right)$ for contract $\mathrm{i}$ (i-th sub-group) is defined by the formula:

$$
m\left(\theta_{i}\right)=E\left(X_{i, t+1} \mid \Theta_{i}=\theta_{i}\right) .
$$


Since we do not know $\theta_{i}$ parameter value, the value of net contributions is unknown.

The premium calculated as a weighted average from the premium for the entire portfolio, i.e. collective premiums $\mu=E X_{i j}=\frac{1}{N t} \sum_{i=1}^{N} \sum_{j=1}^{t} x_{i j}$ and individual premium $\bar{x}_{i}=\frac{1}{t} \sum_{j=1}^{t} x_{i j}$ in the form:

$$
m\left(\theta_{i}\right)=Z_{i} \bar{x}_{i}+\left(1-Z_{i}\right) \mu
$$

is called a credibility premium for the the $i$-th contract (the $i$-th sub-group), where $Z_{i} \in[0,1]$ is a credibility factor (Kowalczyk, Poprawska, Ronka-Chmielowiec, 2006: 89).

The estimator of variable $X_{i, t+1}$ is called a predictor of this variable, while the predictor's value is called a forecast for $X_{i, t+1}$ based on observations $x_{i 1}, \ldots, x_{i t}$. The basis of the credibility theory is the Bayesian statistical analysis with quadratic loss function (Krzyśko, 1996: 42).

One of the tasks of the credibility theory is to determine the values of the credibility $Z_{i}$ factor. A small value of the coefficient means that the collective premium is more credible for the insurer than individual premium.

\section{Bülmann-Straub model}

The Bülmann-Straub model is a modified Bülmann model (Bühlmann, 1967), in which the number of policies included in the portfolio of individual subgroups does not have to be equal and which takes into account the importance of contracts in the portfolio. Also, the number of policies may vary periodically (Denuit, Marechal, Pitrebois, Walhin, 2007: 126).

Model takes into account the weights (ie. the volume of risk) $w_{i j}$ of random variables $X_{i j}$. If the random variable $X_{i j}$ denotes the arithmetic average of $w_{i j}$ independent random variables with the same distributions, then the numbers $w_{i j}$ are natural weights. In this model, insurance histories may have different lenghts $t_{i}$ for different contracts $i$. The structure of the data in the model are presented in table 1 (Jasiulewicz, 2005). 
Table 1. Structure of data in the Bülmann-Straub model

\begin{tabular}{|c|c|c|c|c|}
\hline \multirow{2}{*}{$\begin{array}{c}\text { Groups } \\
\text { of policies }\end{array}$} & \multicolumn{4}{|c|}{ Years of insurance } \\
\hline & 1 & 2 & $\ldots$ & $t$ \\
\hline 1 & $\begin{array}{l}x_{11} \\
w_{11}\end{array}$ & $\begin{array}{l}x_{12} \\
w_{12}\end{array}$ & $\cdots$ & $\begin{array}{l}x_{1 t} \\
w_{1 t}\end{array}$ \\
\hline 2 & $\begin{array}{l}x_{21} \\
w_{21}\end{array}$ & $\begin{array}{l}x_{22} \\
w_{22}\end{array}$ & $\ldots$ & $\begin{array}{l}x_{2 t} \\
w_{2 t}\end{array}$ \\
\hline$\ldots$ & $\cdots$ & $\cdots$ & $\cdots$ & $\cdots$ \\
\hline$N$ & $\begin{array}{l}x_{N 1} \\
w_{N 1}\end{array}$ & $\begin{array}{l}x_{N 2} \\
w_{N 2}\end{array}$ & $\cdots$ & $\begin{array}{l}x_{N t} \\
w_{N t}\end{array}$ \\
\hline
\end{tabular}

Source: Jasiulewicz, 2005

As previously assigned, let $\mathbf{X}_{i}=\left(X_{i 1}, \ldots, X_{i t}\right)$ be a vector of observation of the number of damages for $i$-th policy ( $i$-th subgroup of policies) during last $t$ years, and let random variable $\Theta_{i}$, represent the structure of risk in portfolio.

The assumptions of the Bülmann-Straub model (Bülmann, Straub, 1970):

1) For given $i$ and $\Theta_{i}=\theta_{i}$, random variables $X_{i 1}, \ldots, X_{i t}$ are independent and

$$
\begin{gathered}
\mathrm{E}\left(X_{i j} \mid \theta_{i}\right)=m\left(\theta_{i}\right), \\
\operatorname{Var}\left(X_{i j} \mid \theta_{i}\right)=\frac{s^{2}\left(\theta_{i}\right)}{w_{i j}}
\end{gathered}
$$

for $i=1, \ldots, N, j=1, \ldots, t$, wherein variables $w_{i j}$ are known.

2) Pairs $\left(\Theta_{1}, \mathbf{X}_{1}\right), \ldots,\left(\Theta_{N}, \mathbf{X}_{N}\right)$ are mutually independent and random variables $\Theta_{1}, \ldots, \Theta_{N}$ are independent and have the same distributions.

Let there be given:

- $\quad$ the average amount of damages for the $i$-th sub-group of policies:

$$
\bar{X}_{i w}=\sum_{j=1}^{t} \frac{w_{i j}}{w_{i}} X_{i j}, \quad w_{i}=\sum_{j=1}^{t} w_{i j}
$$

the average amount of damage for the portfolio:

$$
\bar{X}_{w w}=\sum_{i=1}^{N} \frac{w_{i}}{w} \bar{X}_{i w}, \quad w=\sum_{i=1}^{N} w_{i}
$$

- structural parameters of risk in portfolio:

$$
\mu=\operatorname{Em}\left(\Theta_{i}\right)=E X_{i j}, \quad \phi=E s^{2}\left(\Theta_{i}\right), \quad \psi=\operatorname{Var}\left(m\left(\Theta_{i}\right)\right)
$$


where:

$\mu$-collective net premium, which is a weighted average of the individual net premiums $m\left(\theta_{i}\right)$; the overall mean, it is the expected value of the claim amount for an arbitrary policyholder in the portfolio,

$\varphi$ - describes the average volatility of claims in a group (variation within the group),

$\psi$ - describes the variation of claims between groups.

It can be proved that if the assumptions of the Bülmann-Straub model are met, then (Kass, Goovaerts, Dhaene, Denuit, 2001: 144):

1. Best inhomogeneous linear predictor $\tilde{m}_{i}=E\left(X_{i n+1} \mid \mathbf{X}_{i}\right)$ of the risk premium $m\left(\Theta_{i}\right)$ in the sense of least mean square error is of the form:

$$
\tilde{m}_{i}=Z_{i} \bar{X}_{i w}+\left(1-Z_{i}\right) \mu
$$

where the trust factor is $Z_{i}=\frac{w_{i} \psi}{w_{i} \psi+\varphi}$.

2. Best homogeneous linear predictor $\widetilde{m}_{i}^{*}$ of net premium $m\left(\Theta_{i}\right)$ in the sense of least mean square error is of the form:

$$
\tilde{m}_{i}^{*}=Z_{i} \bar{X}_{i w}+\left(1-Z_{i}\right) \bar{X}_{z w}
$$

where the trust factor is $Z_{i}=\frac{w_{i} \psi}{w_{i} \psi+\varphi}$ and $\bar{X}_{z w}=\sum_{i=1}^{N} \frac{Z_{i}}{Z} \bar{X}_{i w}, \quad Z=Z_{1}+\ldots+Z_{N}$.

It can be proved that if the assumptions of the Bülmann-Straub model are met, then unbiased estimators of structural parameters in the portfolio are of the form (Kass, Goovaerts, Dhaene, Denuit, 2001: 157):

$$
\hat{\mu}=\bar{X}_{z w}, \hat{\phi}_{N}=M S W, \hat{\psi}=\frac{w(N-1)(M S B-M S W)}{w^{2}-\sum_{i=1}^{N} w_{i}^{2}},
$$

where:

$S S W=\sum_{i=1}^{N} \sum_{j=1}^{t} w_{i j}\left(X_{i j}-\bar{X}_{i w}\right)^{2}-$ the weighted sum of squares of deviations within groups (sum-of-squares-within);

$M S W=\frac{S S W}{(t-1) N}-$ the average weighted sum of squares of deviations within groups (mean-square-within); 
$S S B=\sum_{i=1}^{N} w_{i}\left(\bar{X}_{i w}-\bar{X}_{w w}\right)^{2}-$ the weighted sum of squares of deviations between groups (sum-of-squares-between);

$M S B=\frac{S S B}{N-1}-$ the average weighted sum of squares of deviations between groups (mean-square-between).

If the assumptions of the Bülmann-Straub model are met, the average square error of homogenous and inhomogeneous predictor of credibility premium $m\left(\Theta_{i}\right)$ are respectively (Daykin, Pentikäinen, Pesonen, 1994: 186):

$$
\begin{gathered}
M S E_{i}=E\left(m\left(\Theta_{i}\right)-\tilde{m}_{i}\right)^{2}=\left(1-Z_{i}\right) \psi, \\
M S E_{i}^{*}=E\left(m\left(\Theta_{i}\right)-\widetilde{m}_{i}^{*}\right)^{2}=\left(1-Z_{i}\right) \psi\left(1+\frac{1-Z_{i}}{Z}\right)
\end{gathered}
$$

for $i=1, \ldots, N$.

\section{An example of application of the model for the evaluation of the bonus-malus premium rates}

Empirical research was carried out based on the data from the portfolio of the third party liability insurance of individual motor vehicle owners for the time period of four years. Distribution of the insured into bonus-malus classes is consistent with the classification of the insurer. The isolated number of claims and the division into classes according to the value of paid claims is consistent with the ratemaking of insurer.

Table 2 shows the bonus-malus system of the audited insurance company (slightly modified in order to preserve the anonymity of the insurance company). This system consists of 10 classes, including three with the increase in the premiums and six with discounts. The insured are assigned to particular classes in a given year by the number of damages reported in the previous year.

The biggest group in the portfolio (average $87 \%$ ) in the analyzed period were the insured holding a $60 \%$ discount of the contribution (which is assigned to the first class of the system, in which the premium rate was $40 \%$ ). In the second and third class were, respectively, $4 \%$ and $3 \%$ of the insured. In each of the increase classes the participation of the insured in each of the studied years constituted less than $1 \%$. 
Table 2. Bonus-malus system of the audited insurance company

\begin{tabular}{|c|c|c|c|c|}
\hline \multirow{2}{*}{ BM class } & \multirow{2}{*}{ Premium rate [\%] } & \multicolumn{4}{|c|}{ BM class } \\
& & $\mathbf{0}$ & $\mathbf{1}$ & $\geq \mathbf{2}$ \\
\cline { 3 - 5 } & & 1 & 3 & 10 \\
\hline 1 & 40 & 1 & 4 & 10 \\
\hline 2 & 50 & 2 & 5 & 10 \\
\hline 3 & 60 & 3 & 6 & 10 \\
\hline 4 & 70 & 4 & 7 & 10 \\
\hline 5 & 80 & 5 & 8 & 10 \\
\hline 6 & 90 & 6 & 9 & 10 \\
\hline 7 & 100 & 7 & 10 & 10 \\
\hline 8 & 125 & 8 & 10 & 10 \\
\hline 9 & 180 & 9 & 10 & 10 \\
\hline 10 & 250 & & & \\
\hline
\end{tabular}

Source: insurance company

Figure 1 shows the average number of claims in bonus-malus classes in the studied years. For the analyzed period of time differences in the average number of claims in each class can be observed. In general, the highest number of claims is observed in the classes with the increase in the rate of $100 \%$ of the premium, while the lowest in the first class of the system.

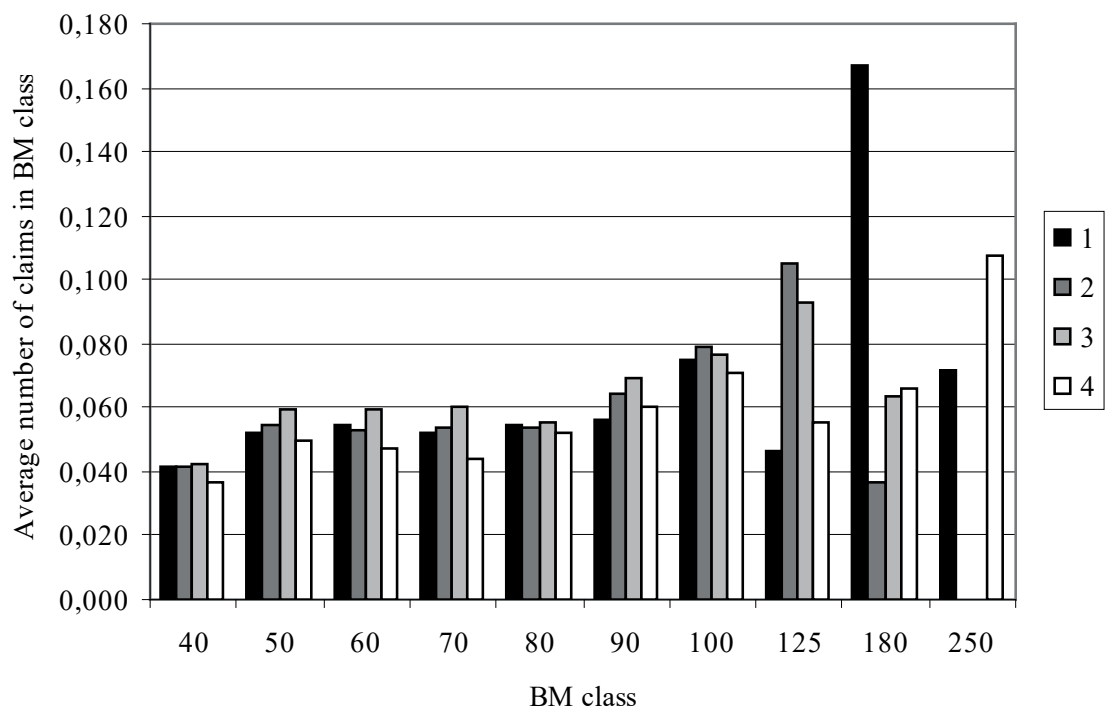

Figure 1. The average value of claims paid in the motor liability insurance portfolio in the studied years according to bonus-malus classes

Source: own study 
Figures 2 and 3 show the structure of the portfolio in terms of value of claims paid in particular bonus-malus classes.

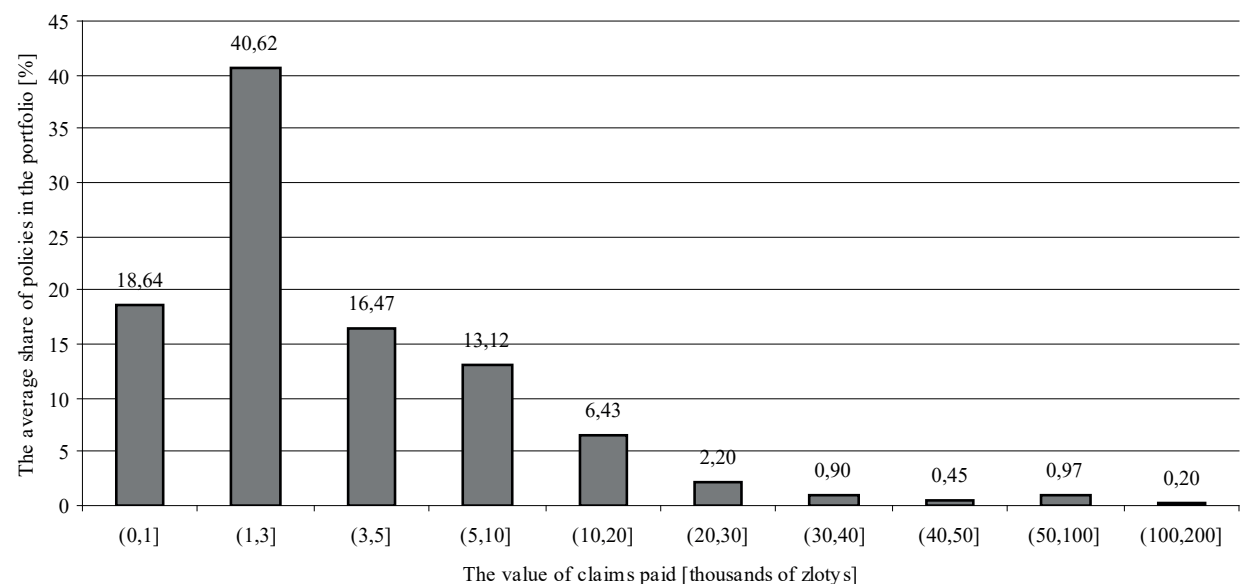

Figure 2. The structure of policies in the portfolio by value of claims paid (on average in the studied years) [\%]

Source: own study

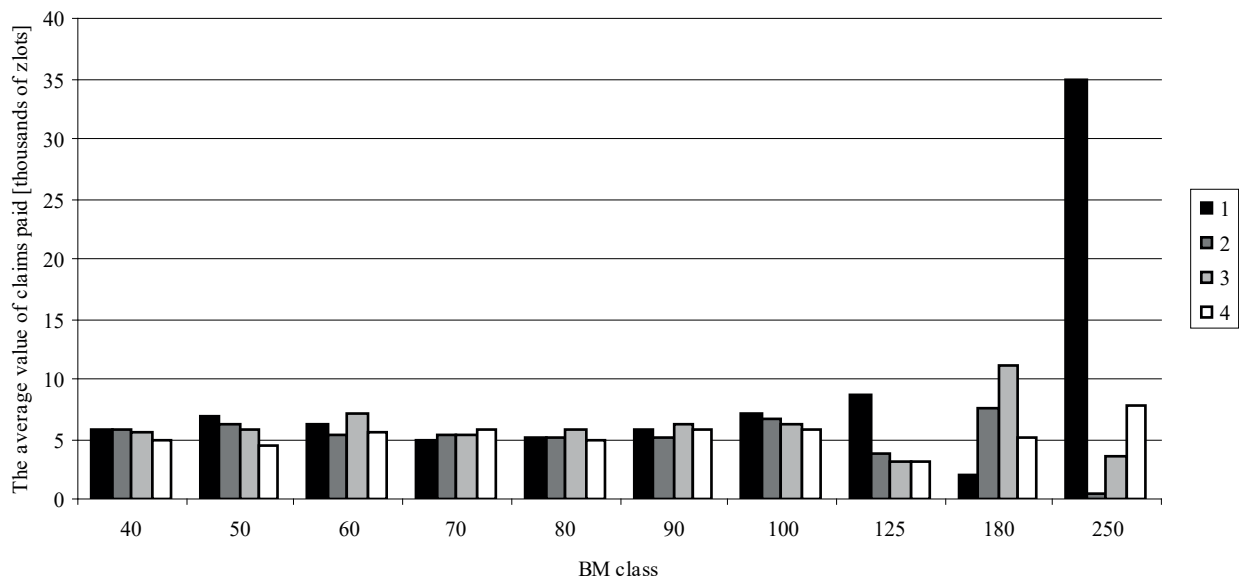

Figure 3. The average value of claims paid in the motor liability insurance portfolio in the studied years according to bonus-malus classes

Source: own study

Compensations up to 10 thousand zlotys constitute on average, in the studied years, $89 \%$ of payments in the portfolio. The fraction of remaining payments is on average $11 \%$. However, it should be noted, that the average sum of the payments from these $89 \%$ of policies is approximately 246 thousand zlotys per year, and the remaining $11 \%$ of insurance policies is over 300 thousand zlotys per year. Approx- 
imately $33 \%$ of the damage of the portfolio in each of the studied years are damages of 1 to 3 thousand zlotys, reported in class 1 or the class with the maximum discount. The average value of compensation paid to each discount class is about 5 to 6 thousand zlotys. Classes with the increase in the contributions are more diverse in terms of the average value of payments in the surveyed years (cf. Figure 3).

In motor liability insurance individual contribution of net premium in period $t+1$ is determined on the basis of the equation (Szymańska, 2014):

$$
\Pi(X, K)=(E X) \cdot(E K) \cdot b_{t+1}
$$

where $\Pi(X, K)$ - individual net premium for the period $t+1, E X-$ the expected value of a single damage in the portfolio, $E K$ - the expected value of the number of claims for individual insurance portfolio, $b_{t+1}$ - premium rate in the period $t+1$ In the actuarial literature, the independence between random variables of number and value of the damage is assumed.

Table 3. Predictors of expected value of damage, the coefficients of credibility and estimation errors by bonus-malus classes

\begin{tabular}{|c|c|c|c|c|c|}
\hline $\boldsymbol{i}$ & ${ }^{X} Z_{i}$ & $\begin{array}{c}{ }^{X} \tilde{m}_{i}^{*} \\
\text { [thousands } \\
\text { of zlotys] }\end{array}$ & $\begin{array}{c}{ }^{X} \tilde{m}_{i} \\
\text { [thousands } \\
\text { of zlotys] }\end{array}$ & $\begin{array}{c}{ }^{X} M S E_{i}^{*} \\
\text { [thousands } \\
\text { of zlotys] }\end{array}$ & $\begin{array}{c}{ }^{X} M S E_{i} \\
\text { [thousands } \\
\text { of zlotys] }\end{array}$ \\
\hline 1 & 0,7856 & 5,46 & 5,43 & 0,007132 & 0,006229 \\
\hline 2 & 0,1845 & 5,63 & 5,52 & 0,036744 & 0,023686 \\
\hline 3 & 0,1326 & 5,72 & 5,60 & 0,039969 & 0,025194 \\
\hline 4 & 0,0748 & 5,62 & 5,49 & 0,043683 & 0,026873 \\
\hline 5 & 0,0661 & 5,61 & 5,48 & 0,044257 & 0,027128 \\
\hline 6 & 0,0878 & 5,65 & 5,52 & 0,042835 & 0,026495 \\
\hline 7 & 0,1434 & 5,75 & 5,63 & 0,039293 & 0,024882 \\
\hline 8 & 0,0022 & 5,63 & 5,49 & 0,048534 & 0,028982 \\
\hline 9 & 0,0017 & 5,63 & 5,50 & 0,048567 & 0,028996 \\
\hline 10 & 0,0004 & 5,64 & 5,50 & 0,048656 & 0,029034 \\
\hline
\end{tabular}

Notes: ${ }^{X} Z_{i}$-coefficient of expected credibility value of damage in $i$-th group,

${ }^{X} \widetilde{m}_{i}^{*}$ - the best homogeneous predictor of expected value of damage in $i$-th group,

${ }^{X} \widetilde{m}_{i}$ - the best heterogeneous predictor of expected value of damage in $i$-th group,

${ }^{X} M S E_{i}^{*}$ - the mean square error of homogenous predictor of expected value of damage,

${ }^{X} M S E_{i}$ - the mean square error of heterogeneous predictor of expected value of damage.

\section{Source: own study}

The aim of this paper is to determine the coefficient $b_{t+1}$ constituting increase or discount of the premium, dependent on the bonus-malus class. Net premiums have been estimated based on the Bülmann-Straub model. 
Models based on the theory of reliability do not require assumptions about the form of a random variable distribution describing the size of individual damage in the portfolio and the values of the parameters of this distribution.

The credibility premium was determined by multiplying the expected value of payments and the expected number of claims, estimated on the basis of the Bühlmann-Straub model. Two cases were considered: when the premium reliability is a homogeneous predictor and heterogeneous predictor of net premium. Tables 3 and 4 show the results of the estimation.

Table 4. Predictors of expected value of damage, the coefficients of credibility and estimation errors by bonus-malus classes

\begin{tabular}{|c|c|c|c|c|c|}
\hline $\boldsymbol{i}$ & ${ }^{K} Z_{i}$ & ${ }^{K} \widetilde{m}_{i}^{*}$ & ${ }^{K} \tilde{m}_{i}$ & ${ }^{K} M S E_{i}^{*}$ & ${ }^{K} M S E_{i}$ \\
\hline 1 & 0,9980 & 0,0404 & 0,0404 & 0,00000035 & 0,00000035 \\
\hline 2 & 0,9592 & 0,0534 & 0,0529 & 0,00000727 & 0,00000723 \\
\hline 3 & 0,9404 & 0,0540 & 0,0532 & 0,00001065 & 0,00001056 \\
\hline 4 & 0,8940 & 0,0532 & 0,0517 & 0,00001905 & 0,00001876 \\
\hline 5 & 0,8788 & 0,0542 & 0,0525 & 0,00002183 & 0,00002144 \\
\hline 6 & 0,8959 & 0,0619 & 0,0605 & 0,00001870 & 0,00001842 \\
\hline 7 & 0,9265 & 0,0743 & 0,0733 & 0,00001315 & 0,00001301 \\
\hline 8 & 0,1430 & 0,0584 & 0,0467 & 0,00017084 & 0,00015169 \\
\hline 9 & 0,1050 & 0,0587 & 0,0464 & 0,00017930 & 0,00015842 \\
\hline 10 & 0,0476 & 0,0558 & 0,0428 & 0,00019223 & 0,00016858 \\
\hline
\end{tabular}

Notes: ${ }^{K} Z_{i}$ - coefficient of expected credibility value of damage in $i$-th portfolio group,

${ }^{K} \widetilde{m}_{i}^{*}$ - the best homogeneous predictor of the expected number of claims in the $i$-th portfolio group,

${ }^{K} \widetilde{m}_{i}$ - the best heterogeneous predictor of the expected number of claims in the $i$-th portfolio group,

${ }^{K} M S E_{i}^{*}$ - the mean square error of homogenous predictor of expected value of damage,

${ }^{K} M S E_{i}$ - the mean square error of heterogeneous predictor of expected value of damage.

Source: own study

Taking into account equations (13), (8) and (9) the value of net premium (credibility premium) was determined respectively from the formulas:

$$
\begin{aligned}
& \Pi_{i}(X, K)={ }^{X} \widetilde{m}_{i} \cdot{ }^{K} \widetilde{m}_{i} \cdot{ }_{i} b_{t+1}, \\
& \Pi_{i}(X, K)={ }^{X} \widetilde{m}_{i}^{*} \cdot{ }^{K} \widetilde{m}_{i}^{*} \cdot{ }_{i} b_{t+1}^{*} .
\end{aligned}
$$

The premium rate in each bonus-malus class was calculated as the quotient of net premium in the bonus-malus class and net premium in the portfolio: 


$$
\begin{aligned}
& { }_{i} b_{t+1}=\frac{{ }^{X} \tilde{m}_{i} \cdot{ }^{K} \tilde{m}_{i}}{{ }^{X} \tilde{m}_{\text {portf }} \cdot{ }^{K} \widetilde{m}_{\text {portf }}}, \\
& { }_{i} b_{t+1}^{*}=\frac{{ }^{X} \widetilde{m}_{i}^{*} \cdot{ }^{K} \widetilde{m}_{i}^{*}}{{ }^{X} \tilde{m}_{\text {portf }}^{*} \cdot{ }^{K} \tilde{m}_{\text {portf }}^{*}},
\end{aligned}
$$

where: ${ }^{X} \widetilde{m}_{\text {portf }}$ - the best heterogeneous predictor of the expected number of claims in the portfolio,

${ }^{K} \widetilde{m}_{\text {portf }}$ - the best heterogeneous predictor of the expected number of claims in the portfolio,

${ }^{X} \widetilde{m}_{\text {portf }}^{*}$ - the best homogeneous predictor of the expected number of claims in the portfolio,

${ }^{K} \tilde{m}_{\text {portf }}^{*}$ - the best homogeneous predictor of the expected number of claims in the portfolio.

The value of credibility premiums and net premium rates have been presented in table 5.

Table 5. Credibility premiums and net premium rates by bonus-malus classes

\begin{tabular}{|c|c|c|c|c|c|c|}
\hline \multirow{2}{*}{ BM class } & \multicolumn{2}{|c|}{$\begin{array}{c}\text { Credibility premium } \\
\text { [thousands of zlotys] }\end{array}$} & \multicolumn{2}{c|}{$\begin{array}{c}\text { Premium } \\
\text { rate }\end{array}$} & \multicolumn{2}{c|}{$\begin{array}{c}\text { Estimation error } \\
\text { [thousands of zlotys] }\end{array}$} \\
\cline { 2 - 7 } & $X \tilde{m}_{i} \cdot{ }^{K} \tilde{m}_{i}^{*}$ & ${ }^{X} \tilde{m}_{i} \cdot{ }^{K} \tilde{m}_{i}$ & ${ }_{i} b_{t+1}^{*}$ & ${ }_{i} b_{t+1}$ & $M S E_{i}^{*}$ & $M S E_{i}$ \\
\hline 1 & 0,22030 & 0,21894 & 0,69 & 0,93 & 0,0000000025 & 0,0000000022 \\
\hline 2 & 0,30103 & 0,29185 & 0,95 & 1,24 & 0,0000002671 & 0,0000001711 \\
\hline 3 & 0,30902 & 0,29789 & 0,97 & 1,27 & 0,0000004256 & 0,0000002659 \\
\hline 4 & 0,29895 & 0,28409 & 0,94 & 1,21 & 0,0000008322 & 0,0000005041 \\
\hline 5 & 0,30389 & 0,28772 & 0,96 & 1,23 & 0,0000009660 & 0,0000005817 \\
\hline 6 & 0,35010 & 0,33432 & 1,10 & 1,42 & 0,0000008011 & 0,0000004880 \\
\hline 7 & 0,42684 & 0,41228 & 1,34 & 1,76 & 0,0000005167 & 0,0000003237 \\
\hline 8 & 0,32896 & 0,25629 & 1,03 & 1,09 & 0,0000082916 & 0,0000043964 \\
\hline 9 & 0,33057 & 0,25497 & 1,04 & 1,09 & 0,0000087082 & 0,0000045935 \\
\hline 10 & 0,31459 & 0,23502 & 0,99 & 1,00 & 0,0000093531 & 0,0000048946 \\
\hline portfolio & 0,31794 & 0,23473 & 1,00 & 1,00 & & \\
\hline
\end{tabular}

Source: own study

Premium rates determined by the credibility method and in particular bonus-malus classes differ significantly from those used in the analyzed insurance company. The estimated rates are higher than those used by the insurer in discount classes, while the lower in increase classes. The analysis shows that the maximum discount should be $30 \%$. Class 7 , which in the audited insurance company is the class with a stake of $100 \%$ of the premium in conducted analysis should be a class with an increase in the contribution of at least $30 \%$ of the premium. 
However, attention should be paid to the small amounts of the credibility coefficients achieved by the estimation of damage in all of the bonus-malus classes, except the first one. They imply low credibility of the individual premium determined on the basis of observations for particular bonus-malus classes. According to the credibility theory, it may be caused by a small number of observations in the subgroups (here the bonus-malus classes), small variation between subgroups in terms of the amount (value) of damage or major fluctuations in the amount (number) of damage in time within the subgroups.

In the analyzed portfolio, classes with an increase in the premium were characterized by high variability of the average amount and the number of claims in time. Since the aim of the study was to determine the premium rates in the bonus-malus classes of the analyzed portfolio and not to determine the very premium, the data was corrected in the classes with premium increase. This correction consisted in assuming the average value and the average amount of damage in each increase bonus-malus class, being equal to their maximum values obtained in the studied years.

It was assumed that: $X_{i j}=\max _{j} X_{i j}, K_{i j}=\max _{j} K_{i j}, i \in\{8,9,10\}$. The estimation results have been presented in tables 6-8.

Table 6. Predictors of expected value of damage, the coefficients of credibility and estimation errors by bonus-malus classes after data correction

\begin{tabular}{|c|c|c|c|c|c|}
\hline $\boldsymbol{i}$ & ${ }^{X} Z_{i}$ & $\begin{array}{c}{ }^{X} \tilde{m}_{i}^{*} \\
\text { [thousands } \\
\text { of zlotys] }\end{array}$ & $\begin{array}{c}{ }^{X} \tilde{m}_{i} \\
\text { [thousands } \\
\text { of zlotys] }\end{array}$ & $\begin{array}{c}{ }^{X} M S E_{i}^{*} \\
\text { [thousands } \\
\text { of zlotys] }\end{array}$ & $\begin{array}{c}{ }^{X} M S E_{i} \\
\text { [thousands } \\
\text { of zlotys] }\end{array}$ \\
\hline 1 & 0,9969 & 5,41 & 5,41 & 0,007068 & 0,007065 \\
\hline 2 & 0,9525 & 5,70 & 5,63 & 0,109979 & 0,109270 \\
\hline 3 & 0,9313 & 6,35 & 6,24 & 0,159624 & 0,158140 \\
\hline 4 & 0,8776 & 5,65 & 5,46 & 0,286491 & 0,281780 \\
\hline 5 & 0,8625 & 5,52 & 5,31 & 0,322524 & 0,316577 \\
\hline 6 & 0,8951 & 5,96 & 5,80 & 0,244801 & 0,241346 \\
\hline 7 & 0,9369 & 6,46 & 6,36 & 0,146595 & 0,145342 \\
\hline 8 & 0,3267 & 7,57 & 6,53 & 0,692280 & 0,549782 \\
\hline 9 & 0,3064 & 8,33 & 7,27 & 0,747698 & 0,596482 \\
\hline 10 & 0,2374 & 13,70 & 12,53 & 0,937917 & 0,755150 \\
\hline
\end{tabular}

Source: own study 
Table 7. Predictors of expected value of damage, the coefficients of credibility and estimation errors by bonus-malus classes after data correction

\begin{tabular}{|c|c|c|c|c|c|}
\hline $\boldsymbol{i}$ & ${ }^{K} Z_{i}$ & ${ }^{K} \tilde{m}_{i}^{*}$ & ${ }^{K} \tilde{m}_{i}$ & ${ }^{K} M S E_{i}^{*}$ & ${ }^{K} M S E_{i}$ \\
\hline 1 & 0,9983 & 0,0404 & 0,0403 & 0,00000033 & 0,00000033 \\
\hline 2 & 0,9653 & 0,0535 & 0,0530 & 0,00000680 & 0,00000676 \\
\hline 3 & 0,9491 & 0,0541 & 0,0533 & 0,00000998 & 0,00000991 \\
\hline 4 & 0,9089 & 0,0534 & 0,0520 & 0,00001797 & 0,00001773 \\
\hline 5 & 0,8957 & 0,0544 & 0,0528 & 0,00002063 & 0,00002032 \\
\hline 6 & 0,9106 & 0,0624 & 0,0610 & 0,00001763 & 0,00001741 \\
\hline 7 & 0,9372 & 0,0777 & 0,0768 & 0,00001235 & 0,00001224 \\
\hline 8 & 0,1649 & 0,0670 & 0,0531 & 0,00018232 & 0,00016265 \\
\hline 9 & 0,1219 & 0,0725 & 0,0579 & 0,00019276 & 0,00017102 \\
\hline 10 & 0,0558 & 0,0621 & 0,0463 & 0,00020903 & 0,00018389 \\
\hline
\end{tabular}

Source: own study

Table 8. Credibility premiums and net premium rates by bonus-malus classes after data correction

\begin{tabular}{|c|c|c|c|c|c|c|}
\hline \multirow{2}{*}{ BM class } & \multicolumn{2}{|c|}{$\begin{array}{c}\text { Credibility premium } \\
\text { [thousands of zlotys] }\end{array}$} & \multicolumn{2}{c|}{$\begin{array}{c}\text { Premium } \\
\text { rate }\end{array}$} & \multicolumn{2}{c|}{$\begin{array}{c}\text { Estimation error } \\
\text { [thousands of zlotys] }\end{array}$} \\
\cline { 2 - 7 } & ${ }^{X} \tilde{m}_{i}{ }^{*} \cdot{ }^{K} \tilde{m}_{i}^{*}$ & ${ }^{X} \tilde{m}_{i} \cdot{ }^{K} \tilde{m}_{i}$ & ${ }_{i} b_{t+1}^{*}$ & ${ }_{i} b_{t+1}$ & $M S E_{i}^{*}$ & $M S E_{i}$ \\
\hline 1 & 0,21853 & 0,21819 & 0,52 & 0,92 & 0,0000000023 & 0,0000000023 \\
\hline 2 & 0,30518 & 0,29823 & 0,73 & 1,26 & 0,0000007473 & 0,0000007388 \\
\hline 3 & 0,34375 & 0,33308 & 0,82 & 1,41 & 0,0000015930 & 0,0000015667 \\
\hline 4 & 0,30178 & 0,28394 & 0,72 & 1,20 & 0,0000051477 & 0,0000049972 \\
\hline 5 & 0,30037 & 0,28018 & 0,72 & 1,19 & 0,0000066534 & 0,0000064336 \\
\hline 6 & 0,37193 & 0,35375 & 0,89 & 1,50 & 0,0000043167 & 0,0000042014 \\
\hline 7 & 0,50196 & 0,48817 & 1,20 & 2,07 & 0,0000018100 & 0,0000017783 \\
\hline 8 & 0,50693 & 0,34656 & 1,21 & 1,47 & 0,0003085296 & 0,0002520754 \\
\hline 9 & 0,60417 & 0,42038 & 1,44 & 1,78 & 0,0003368939 & 0,0002730372 \\
\hline 10 & 0,85070 & 0,58051 & 2,03 & 2,46 & 0,0004050808 & 0,0003227614 \\
\hline portfel & 0,41995 & 0,23634 & 1,00 & 1,00 & & \\
\hline
\end{tabular}

Source: own study 
Table 9. The premium rate in the audited insurance company estimated by the credibility method for the actual data and after correction

\begin{tabular}{|c|c|c|c|c|c|}
\hline \multirow{3}{*}{$\begin{array}{l}\text { BM } \\
\text { class }\end{array}$} & \multicolumn{5}{|c|}{ Premium rate [\%] } \\
\hline & \multirow{2}{*}{$\begin{array}{l}\text { Audited } \\
\text { insurance } \\
\text { company }\end{array}$} & \multicolumn{2}{|c|}{ Homogeneous predictor } & \multicolumn{2}{|c|}{ Heterogenous predictor } \\
\hline & & Actual data & $\begin{array}{c}\text { After } \\
\text { correction }\end{array}$ & Actual data & $\begin{array}{c}\text { After } \\
\text { correction }\end{array}$ \\
\hline 1 & 40 & 69 & 52 & 93 & 92 \\
\hline 2 & 50 & 95 & 73 & 124 & 126 \\
\hline 3 & 60 & 97 & 82 & 127 & 141 \\
\hline 4 & 70 & 94 & 72 & 121 & 120 \\
\hline 5 & 80 & 96 & 72 & 123 & 119 \\
\hline 6 & 90 & 110 & 89 & 142 & 150 \\
\hline 7 & 100 & 134 & 120 & 176 & 207 \\
\hline 8 & 125 & 103 & 121 & 109 & 147 \\
\hline 9 & 180 & 104 & 144 & 109 & 178 \\
\hline 10 & 250 & 99 & 203 & 100 & 246 \\
\hline
\end{tabular}

Source: own study

\section{Conclusions}

The introduction of data correction in the classes with premium increase allowed to improve the credibility of premium in separated classes, according to the bonus-malus portfolio groups, although in the classes with premium increase the credibility coefficients were still low. A possibility to modify the Bühlmann-Straub model and to correct data is one of the advantages of its use, mentioned in the actuarial literature (Kowalczyk, Poprawska, Ronka-Chmielowiec, 2006). As a result of the correction the mean square errors increase and premiums, especially in the last three classes, are overestimated. However, due to the assumption of the maximum average number and amount of damage in the classes with corrected data, the financial management of the insurer is not threatened. It should also be noted that in the Bühlmann-Straub model, the higher the credibility coefficients, the larger the errors in the reliable premium estimation.

Premium rates obtained from the estimation of the data after correction are closer to the rates applied in the audited insurance company. In classes 1-3 with premium discount the estimated rates are higher than insurer's rates. In classes $8-10$ with premium increase the estimated rates are lower than those used by the insurance company, despite their overestimation caused by the data correction. It should be emphasized that the rates for class 7, according to the estimation results, should be higher than those used by the insurer.

The estimated rates after data correction, compared to the rates obtained on the basis of actual data, are lower in classes with premium discount and class 7 and higher in classes with premium increase. 


\section{References}

Antonio K., Valdez E. (2012), Statistical concepts of a priori and a posteriori classification in insurance, "AStA Adv Stat Anal", vol. 96, pp. 187-224.

Bühlmann H. (1967), Experience Rating and Credibility, "ASTIN Bulletin”, vol. 4(3), pp. 199-207.

Bühlmann H., Straub E. (1970), Glaubwürdigkeit für Schadensätze, "Mitteilungen der Vereiningung scheizerischer Vesicherungsmathematiker", p. 111-133.

Daykin C.D., Pentikäinen T., Pesonen M. (1994), Practical Risk Theory for Actuaries, Chapman \& Hall, London.

Denuit M., Marechal X., Pitrebois S., Walhin J.F. (2007), Actuarial Modelling of Claim Counts. Risk classification, Credability and Bonus-Malus Systems, J. Wiley \& Sons, Chichester.

Jasiulewicz H. (2005), Teoria zaufania. Modele aktuarialne, Wydawnictwo Akademii Ekonomicznej im. Oskara Langego we Wrocławiu, Wrocław.

Kaas R., Goovaerts M., Dhaene J., Denuit M. (2001), Modern Actuarial Risk Theory, Kluwer, Boston.

Kowalczyk P., Poprawska E., Ronka-Chmielowiec W. (2006), Metody aktuarialne, Wydawnictwo Naukowe PWN, Warszawa.

Krzyśko M. (1996), Statystyka matematyczna, Wydawnictwo Naukowe UAM, Poznań.

Lemaire J. (1995), Bonus-Malus Systems in Automobile Insurance, Kluwer, Boston.

Ostasiewicz W. (red.), (2000), Modele aktuarialne, Wydawnictwo Akademii Ekonomicznej im. Oskara Langego we Wrocławiu, Wrocław.

Raport o stanie sektora ubezpieczeń po III kwartale 2015 r., Komisja Nadzoru Finansowego, Warszawa 2016 r., www.knf.gov [dostęp: 5.10.2016].

Szymańska A. (2014), Statystyczna analiza systemów bonus-malus w ubezpieczeniach komunikacyjnych, Wydawnictwo Uniwersytetu Łódzkiego, Łódź.

\section{Zastosowanie modelu Bülmanna-Strauba z korektą danych do estymacji stawek składki netto w systemach bonus-malus ubezpieczeń odpowiedzialności cywilnej posiadaczy pojazdów mechanicznych}

Streszczenie: Jednym z elementów procesu taryfikacji w ubezpieczeniach odpowiedzialności cywilnej posiadaczy pojazdów mechanicznych jest system bonus-malus. Uwzględnia on w składce "szkodowość" ubezpieczonego przez zwyżki i zniżki składki bazowej, nazywane stawkami składki netto. Celem artykułu jest zaproponowanie metody estymacji stawek składki netto w klasach bonus-malus portfela ubezpieczeń komunikacyjnych OC osób fizycznych. Do szacowania składki wykorzystano model Bülmanna-Strauba. W celu poprawy wiarygodności oszacowanych stawek składki dokonano korekty danych w klasach ze zwyżką składki. Przykład zastosowania metody zaprezentowano na podstawie danych uzyskanych z jednego z towarzystw ubezpieczeniowych funkcjonujących na polskim rynku, które zastrzegło sobie anonimowość.

Słowa kluczowe: teoria największej wiarygodności, model Bülmanna-Strauba, system bonus-malus, stawki składki netto, ubezpieczenie odpowiedzialności cywilnej posiadaczy pojazdów mechanicznych

JEL: G22, C11, C51 


\begin{tabular}{|l|l|}
\hline \multirow{2}{*}{ OPEN ACCESS } & $\begin{array}{l}\text { C by the author, licensee Łódź University - Łódź University Press, Łódź, Poland. } \\
\text { This article is an open access article distributed under the terms and conditions } \\
\text { of the Creative Commons Attribution license CC-BY } \\
\text { (http: //creativecommons.org/licenses/by/3.0/) }\end{array}$ \\
\cline { 2 - 2 } \\
Received: 2016-12-16; verified: 2017-11-19. Accepted: 2018-03-12
\end{tabular}

